\title{
SUSTAINABLE TOURISM IN DALI \\ (PROGRESS, CHALLENGES AND OPPORTUNITIES)
}

Tianyi, Li - Bujdosó Zoltán

\begin{abstract}
This paper will introduce the progress, challenges and opportunities in the development of ecotourism and sustainable tourism of Dali (A tourist destination in the southwest of China) and some strategies of sustainable tourism used by the local government. Dali is mainly located in the state of the west of Yunnan province, southwest of China. Dali boasts impressive natural scenery, has a brilliant and long history and unique national culture. Cangshan Mountain and Erhai Lake fuse together with the Dali Ancient City, odd mountains and clear water combine with the Bai affectionate feelings, it has become a popular tourist destination at home and abroad. In the main body of this paper, the challenges of tourism development including the environmental situation of Erhai lake, Cangshan mountain protected area, historical and religious heritage and the social situation of the local minority group will be analyzed. In response to these situations, the measures and policies issued by the government will be introduced, and use data statistics to analyze the achievement of ecotourism and sustainable strategies. In the last part, we will make a prediction for future tourism development opportunities.
\end{abstract}

Key word: Sustainable Tourism; Ecotourism; Dali

JEL:Z30

DOI: $10.33032 /$ acr.2020.10.1.141 


\section{Introduction}

\section{Regional Geographical Environment Overview}

Dali is mainly located in the state of west of Yunnan province, southwest of China. The city is $398 \mathrm{~km}$ from the capital of province Kunming. It covers an area of 1,457 square $\mathrm{km}$ and average altitude of $1980 \mathrm{~m}$ that is made up of various geothermal features like Karst, as well as mountains, lakes, canyons, and rivers.

Dali has a temperate tropical plateau monsoon climate; it is like spring all year round. Its annual average temperature is about $15^{\circ} \mathrm{C}$, Because that it has a unique plateau lake Erhai Lake, forming a special suitable geographical climate environment for local people's living and development. (Dali Yearbook, 2019)

Dali boasts impressive natural scenery, has a brilliant and long history and unique national culture. Cangshan Mountain and Erhai Lake fuse together with the Dali Ancient City, odd mountains and clear water combine with the Bai amorous feelings, it has become a popular tourist destination at home and abroad.

\section{Results}

\section{Tourism Resource Overview}

Erhai Lake Travel Resources

Erhai Lake stretches $42 \mathrm{~km}$ from north to south and $3.9 \mathrm{~km}$ from east to west. The lake covers an area of more than 250 square kilometers and 21.5 meters at the deepest. It is ranked the second in Yunnan province and the seventh freshwater lake in China by the area and water storage. Erhai Lake was formed by the subsidence of geological fault. It is reputed as the pearl on plateau for its beautiful scenery and a number of historic sites.

\section{Cangshan Mountain Protected Area Travel Resources}

Cangshan Moutain also called Mt. Diancangshan. Cangshan mountain chain consists of nineteen peaks extend $50 \mathrm{~km}$ north to south in their column formation like screen. The highest peak is 4122 meters above sea level and there are 7 peaks that over 4000 meters. The peaks, straight and magnificent, are overgrown with primeval forests, and crytal-clear waters serpentine among them. Waterfalls and surging river emit thunderous roars. 'Clounds, Snow, Peaks and Streams' are four spectacular views of the Mountain.

\section{Historical and Religious Heritage}

Dali was influence by the culture of Buddhism, there are number of religious and historical culture sightseeing spots, such as Dali ancient city, three pagodas, Chongsheng Monastery, Nanzhao Jianji Big Clock (bell Tower), Yutong Guanyin Hall and so on. 
History of Dali can be dates back to 1382 during the Ming Dynasty and it has been listed among the top historic sites of China. Dali Ancient town was effect by the traditional Bai ethnic culture, the traditional Bai ethnic folk house give the town distinctive feel. (Tao, Y. \& Poungchompu, S., 2018)

\section{Minority Intangible Cultural Heritage}

The Bai ethnic minority group has a population of 1,858,063. Eighty percent are living in communities in the Dali Bai Autonomous Prefecture in Yunnan Province. The Bai community is formed around the $7^{\text {th }}-8^{\text {th }}$ centuries, at the time of the kingdoms of Nanzhao and Dali. Bai minority has its own language, their language belongs to the Sino-Tibetan family, Tibeto-Burman branch. The Bai religion mixes Taoism and local animism, spirits of ancestors and spirits associated with natural elements.

\section{Tourism Development Review}

The beautiful natural scenery, many historical and cultural monuments, rich ancient customs in Dali to become the Yunnan province tourism industry started one of the first region. Since 1980s to late 1990s, Dali tourism industry has been rapid development, has become a popular tourist destination in Yunnan province city.

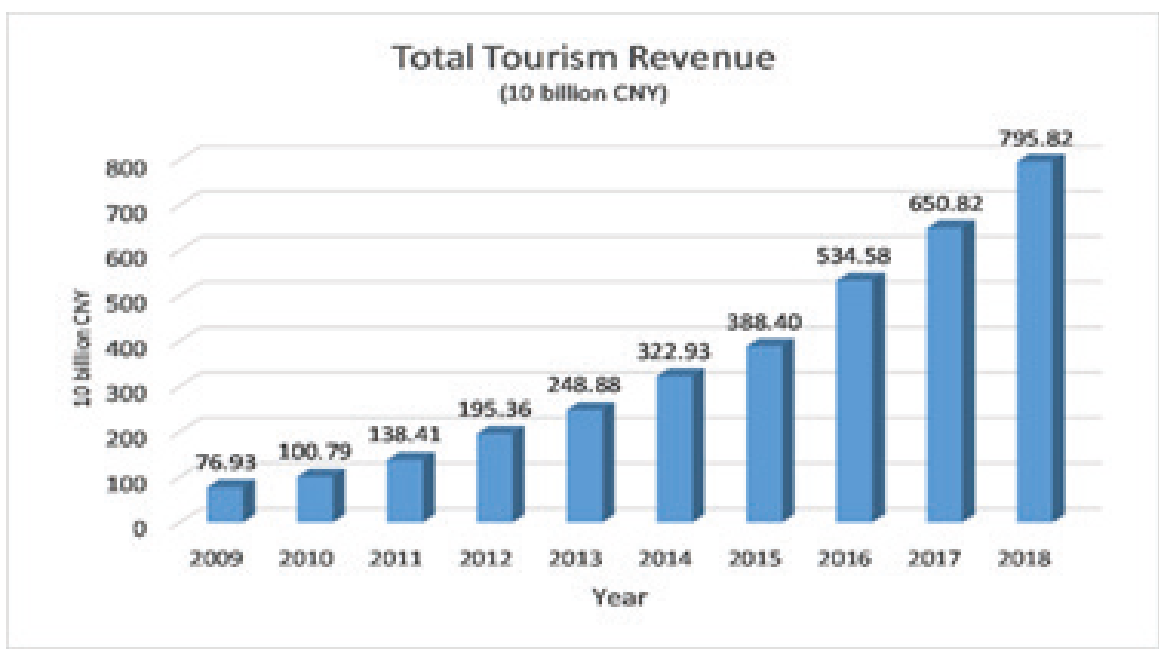

Table 1. Total Tourism Revenue from 2009 to 2018

Source: Dali City Statistical Yearbook (DCBS2009-2018)

As it shown in Table 1 is the rapid increasing in the total tourism revenue over the period from 2009 to 2018. During this nearly decade the number of 2018 has 
increased by $93.4 \%$ as compared with that of 2009 . The tertiary industry in Dali Prefecture generally accounts for a large proportion of GDP in each year. In particular, as the top priority in the tertiary industry, the tourism industry has shown a steady and rising trend of continuous development every year, and has become one of the economic pillars of Dali Prefecture (Table 2).

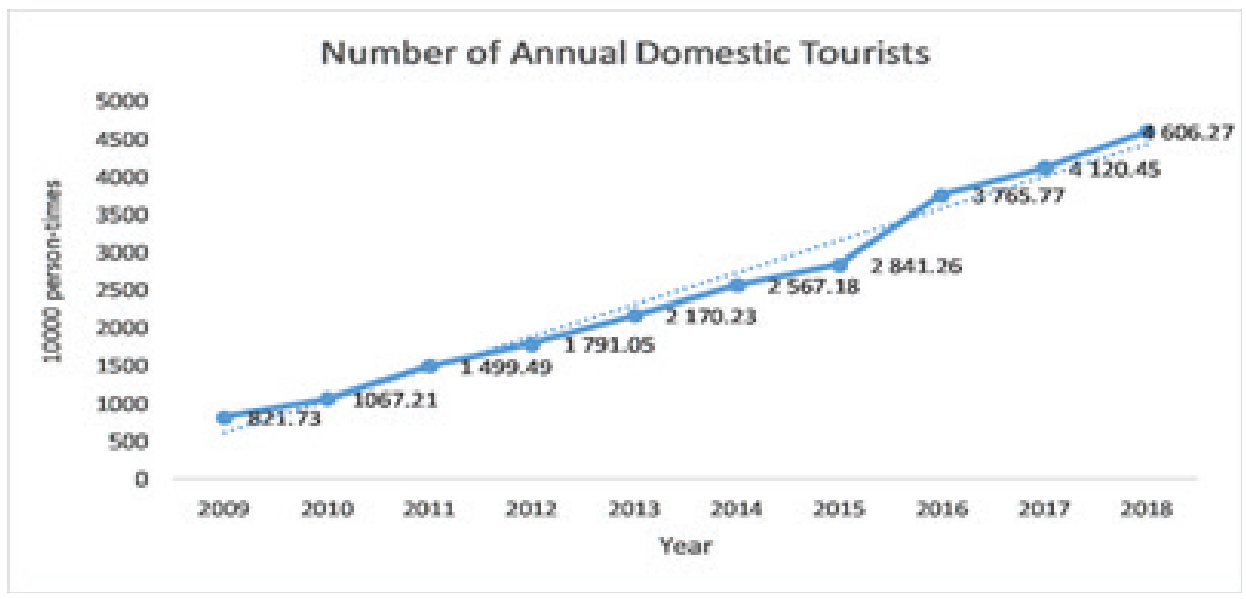

Table 2 Annual Domestic Tourists from 2009 to 2018

Source: Dali City Statistical Yearbook (DCBS2009-2018)

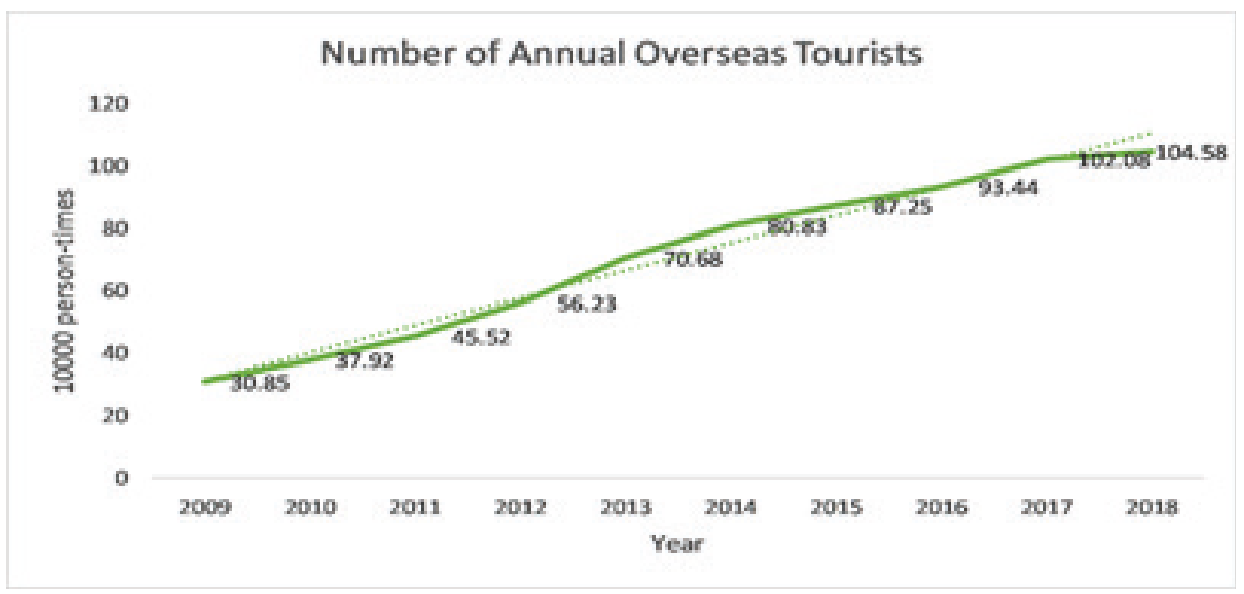

Table 3 Annual Domestic Tourists from 2009 to 2018

Source: Dali City Statistical Yearbook (DCBS2009-2018)

The number of annual domestic tourists and overseas tourists are increased $46 \%$ and $23.9 \%$ separately in this nearly decade (Table 3 ). 


\section{Challenges in the Development of Ecotourism and Sustainable Tourism}

\section{Water Environmental Situation of Erhai Lake}

The main pollution source of Erhai lake is the non-point source pollution, secondly, is lake precipitation and endogenous release, industrial sewage and urban sewage are not the main reason. Non-point source pollution mainly comes from agricultural non-point source pollution. Point source pollution mainly includes industrial pollution sources, hotels along the lake, tourist resorts, etc. The main pollutants exceeded the total phosphorus and mercury, especially the pollution of total phosphorus. Generally, the problem is regional economic development and environment are uncoordinated (Peng, J et al., 2018)

\section{Environmental Situation of Cangshan Protected Area}

The average elevation of Cangshan Mountain is $2741 \mathrm{~m}$. The maximum drops up to $2700 \mathrm{~m}$, with abundant animal and plant resources. According to statistical results, there are nearly 2700 species of vascular plants in Cangshan ecosystem, Of which more than 250 kinds of ferns. In addition, there is some research indicated that While ecotourism promotes environmental protection, it also affects the stability of the local flora. Human activities may pollute the water source. The pollution of the water source will mainly cause changes in the local flora, and it will also bring some pathogenic bacteria. Increasing the risk of intestinal infectious diseases. Therefore, the protection of biodiversity and forestry resource, keep the stability of bacterial community are the challenges of Cangshan Protected Area. (Bhatta, L.D., 2018)

\section{Environmental Situation of Historical and Culture Heritage}

Intangible cultural heritage is the intellectual result of the accumulation of thousands of years for all ethnic groups, and is the common product of spiritual and physical labor of people in all regions. At present, the Dali Bai autonomous prefecture 145 items. Among them, there are 15 nation-level intangible cultural heritage items, 58 provincial-level items and 72 state-level items. They are including folklore, traditional skills, traditional dance, traditional theater, traditional music, traditional art, traditional dramas, traditional medicine and traditional sports.

The challenge and problems in the protection of intangible cultural heritage are the lacks awareness of inheritor its own intellectual property protection and the lack of protection and support from relevant government policies.

\section{Simple Tourism Product Structure}

Innovation in tourism products and tourism models is an effective way to attract more tourists. But in recent years, simple tourism product structure with low ability 
to satisfy the demand of tourists in Dali. According to the present situation, Dali tourism industry will face greater competitive pressures with another surrounding region.

\section{Process of Pollution Prevention and Protection of Water Resources}

Point Source Pollution Control

For point source pollution control, it mainly focuses on industrial pollution sources, lakeside hotels and tourist resorts along the river basin; raising the standards of sewage discharge by the industrial enterprises; increased supervision and inspection; Speeded up the construction of sewage interception pipeline system and the construction of urban sewage treatment plants and garbage disposal sites along the basin; clean several polluted river channels.

Non-point source pollution control

For non-point source pollution control, construction and promotion of ecological agriculture demonstration park, which to improve the effectiveness of reasonable application of pesticides and fertilizers in the river basin and control of nitrogen, phosphorus and organic pollution and improve the pollution control and monitoring of agricultural non-point source; construction of village and town garbage treatment and biogas digesters, and cooperate with technologies such as land treatment systems or purification tanks for human and animal waste and sewage and water treatment systems; soil and water conservation and greening project, based on the original and natural forest protection in the river basin then fully implement ecological restoration project of water conservation forest, Grain for Green Project is one of the most important part of it. (Zhao, H et al., 2018; Tianshan, W \& Han, Z., 2016)

\section{Inheritance and Promotion of Intangible Cultural Heritage}

Intangible cultural heritage facilitates the development of tourism. It stands for a culture symbol of a region, also the best publicity for a tourist destination. (Xin, L., 2011) The inheritance of intangible cultural heritage needs the combined efforts of citizens and governments. On the one hand, the government should actively promote and guide people to learn more the local intangible cultural heritage, on the other hand, the government should invest special funds to support the inheritance of intangible cultural heritage to make the relative industries sustainable development. (Chen, X.L et al., 2011) 


\section{Conclusions}

\section{Opportunities of develop Ecotourism and sustainable tourism}

The government support the development of tourism as a pillar industry and invest a lot of money to support environmental protection to develop eco-tourism. Combining rich natural environment resources and historical heritage resources, and developed modern organic agriculture, it is a good opportunity to development sustainable tourism in Dali. Dominant market of eco-tourism leads an innovative tourism development way, the best choice is to transfer into the vacation destination for leisure travel mode instead of rigid mode before.

\section{Reference}

[1.] Tao, Y. and Poungchompu, S.(2018): The Development of Rural Tourism in The Region of Zhu Kula Village, Dali City, Yunnan Provience, China. In ASEAN/Asian Academic Society International Conference Proceeding Series, pp. 843-848.

[2.] Ni, Z. and Wang, S.(2015): Historical accumulation and environmental risk of nitrogen and phosphorus in sediments of Erhai Lake, Southwest China. Ecological Engineering, 79, pp. 42-53.

[3.] Yearbook, L. (2008-2019): Dali Yearbook.

[4.] Peng, J. - Liu, Y. and Tian, L.(2018): Integrating ecosystem services tradeoffs with paddy land-to-dry land decisions: A scenario approach in Erhai Lake Basin, southwest China. Science of the Total Environment, 625, pp. 849-860.

[5.] Bhatta, L. D. - Wu, N. - Udas, E. - Agrawal, N. K., Ranabhat, S. and Basnet, D.(2018): Wetlands in the Himalaya: Securing Services for LivelihoodsSpecial Publication. P. 49-53.

[6.] Chen, X. L. - Yang, J. D. and Zhang, Y. (2014): Determination and investigation of the influence of national tourism on ethnic identity - .A case study. Shuanglang, Bai village, Dali [J]. Tourism Research, 1.

[7.] Zhao, H. - Zhang, L. - Wang, S. and Jiao, L. (2018): Features and influencing factors of nitrogen and phosphorus diffusive fluxes at the sediment-water interface of Erhai Lake. Environmental Science and Pollution Research, 25(2), pp. 1933-1942. 
[8.] Tianshan, W. and Han, Z. (2016): Analysis of Land Use and Landscape Pattern Change in Erhai Lake during Rapid Urbanization. Ecological Economy, (1), p. 39.

[9.] Xin, L. (2011): On Dali Intangible Cultural Heritage Resources and Library Characteristic Literature Construction. Journal of Dali University, 9.

\section{Authors:}

\section{Li Tianyi}

Earth Science

PhD student

University of Debrecen

tianyi0714@gmail.com

\section{Dr. habil Zoltán Bujdosó}

College Professor

Eszterházy Károly University

Gyöngyös Károly Róbert Campus

bujdoso.zoltan@uni-eszterhazy.hu 